\title{
Shari'ah Governance and Islamic Banks Performance: Evidence from South Asia
}

\author{
Imran Khan * $\quad$ Syeda Nitasha Zahid ${ }^{\dagger} \quad$ Tahir Akhtar ${ }^{\ddagger}$
}

\begin{abstract}
Shari'ah governance provide strike conformity with Islamic businesses ethics and the expectation of its customers which aim at improving firms performance and societal welfare to eliminate poverty in the global setting. The purpose of this study is to investigate the impact of Shari'ah governance on Islamic banks (IBs) performance of 31 IBs of 4 countries of South Asia for the period of 2010-2016 and developed a CG index for IBs. Two types of analysis were performed; descriptive statistics and panel random effects model. It was found that IBs of Bangladesh gets higher ICG scores due to their larger Shari'ah boards, corporate boards, board independence and board meetings compare to others countries. The results of the model show that larger Shari'ah and corporate boards are value enhancing. The study suggests that considering the progressive stage and complexity of competition of IBs with historically mature and financial sound CBs, larger boards with strategic vision may provide IBs the competitive edge in the market.
\end{abstract}

Keywords: Shari'ah governance; financial performance; Islamic banks; South Asia.

\section{Introduction}

Current global financial crisis has highlighted issues concerning conventional governance practices, corporate fairness, ethical principles, transparency and accountability (Beck, Demirgüç-Kunt, \& Merrouche, 2010; Bitar, Madiès, \& Taramasco, 2017; M. Khan \& Khan, 2017). The unprecedented amount of losses born by the world leading financial entities considered as failure to the corporate governance (CG) mechanism of conventional institutions. However, Islamic banks (IBs) perform differently and better than CBs during financial crisis as less exposed to liquidity risk (Kassim \& Abdulle, 2012), better credit and assets growth, contributing to financial and economic stability (Hasan \& Dridi, 2011) and have better financial performance than conventional banking (Perry \& Rehman, 2011). Chazi, Khallaf, and Zantout (2018) argue that during global financial crisis the IBs perform better compared to CBs and exhibited a more prudent risk management behavior and higher solvency. Since, IFIs had been remained stable and credible during the crisis period and proved as an alternative to the conventional counterparts (Aebi, Sabato, \& Schmid, 2012; Chapra, 2009; Green, 2010). Many researchers attributes Islamic banking as an ethical banking since Shari'ah economic laws requires clear transparency in every transaction

\footnotetext{
${ }^{*}$ COMSATS Institute of Information Technology, Pakistan. E-mail: imrankjadoon@ciit.net.pk

${ }^{\dagger}$ COMSATS Institute of Information Technology, Pakistan. E-mail: syeda.nitasha@ymail.com

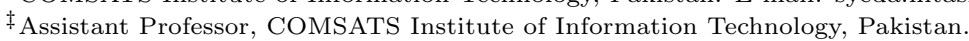


for trading parties (Al-Malkawi \& Pillai, 2018). In an effort to ensure their continuous compliance with Shari'ah economic laws, an additional board composed of Islamic experts in jurisprudence with sufficient knowledge of contemporary finance was emerged and known as Shari'ah supervisory board (SSB). AAOIFI describes SSB as: "an independent body of specialized jurists in Fiqh-al-Muamalat (Islamic commercial jurisprudence) to ensure that Islamic financial institutions are in compliance with Shari'ah principle" (AAOIFI, 2015). In theory, the role of SSB involves providing fatawas (certification on newly developed financial products), conducting Shari'ah audit, calculating zakat, disposal and distribution of Shari'ah non-compliance income, and guide banks on its wider social roles. Their ultimate goal is to preserve the credibility of Islamic financial industry and enhance confidence of stakeholders in products and services of IBs.

The Islamic corporate governance (ICG) theory resembles with stakeholders' oriented theory of CG in which organizations require to serve the interests of all the stakeholders (Bhatti \& Bhatti, 2010; Iqbal, 2001; Mansour \& Bhatti, 2018). According to Chapra and Ahmed (2002) stable and sound financial system depends upon organizations that maintain the stakeholders' confidence. In case of ICG their confidence is achieved by protecting the stakeholders' interest by showing fairness with clear transparency and accountability to all people having any direct or indirect stakes. De Andres and Vallelado (2008) argued that in the framework of CG of banks' role of BODs is subjected to strict regulations, intense competition and higher informational asymmetries. Unlike CBs the governance mechanism of IBs is differ both in BODs and SSBs which is considered as the key component of their governance structure. Therefore, the governance mechanism of IBs is called "multi-layer" governance to ensure Shari'ah compliance in financial activities. IBs faces distinct governance challenges like complex governance structures, Shari'ah compliance issues, existence of IAHs, less transparency and weaker market forces. Further awareness level relating to Islamic banking, its operations and its basic terminologies (use of Arabic words) is low among people that create more hurdles (Islam \& Rahman, 2017) Shari'ah non-adherence risk in addition to other market risks makes the study of CG of IBs more interested.

Islamic banks (IBs) have seen generous development lately because of the increasing demand from the individuals who are religion-delicate and invest as per their personal beliefs and more slanted to connect with banks that consent to Shari'ah rules (Ashraf, Robson, \& Sekhon, 2015). The literature demonstrates that such customers consider a few essential elements while choosing a bank like reputation, religiosity and financial performance and are more inclined to engage with banks that comply with Shari'ah rules (Ashraf et al., 2015).

This study examines the relationship between "multi-layer" corporate governance and firm performance. Specifically, we investigate the effects of Shari'ah and CG attributes on bank performance in case of South Asia. This study contributes into the Islamic finance literature by three ways: (i) we considered a region that consists of $40 \%$ of the Muslims population and are religiously motivated, enormous Islamic banking potential exists in the region, majority of the previous literature on IBs mainly focused on the GCC countries or South East Asia. This study examines a relatively ignored region by investigating the Shari'ah governance and IBs performance. (ii) the study constructed the Islamic Corporate Governance (ICG) Index for IBs that composed of 15 items of the internal governance of 
IBs special focus is given in the construction of the index to the Shari'ah governance characteristics (iii) this is the first study that have examined the impact SSBs characteristics effect on IBs performance in case of South Asia.

\section{Literature Review and Formulation of Hypotheses}

Theoretically as IBs are adherent to social-justice and their business orientation is different from CBs (Hasan \& Dridi, 2011). IBs are supposed to follow the Islamic principles of "fair and just" earnings (i.e. profit and loss sharing model (PLS), impartially distributing the earnings and disallowing "riba" (interest). Therefore, to ensure the continuous compliance with these principles, IBs have put in place the SSBs, as their backers and promoters (Mollah \& Zaman, 2015). Additionally, IBs also improve firm profitability. A comprehensive review by Iqbal (2001) demonstrates that IBs are more stable, profitable and better capitalized than CBs. A study conducted by Saleh Salman, Zeitun, et al. (2006) contend that IBs have higher growth rate both in credit facilities and profitability in case of Jordon. Kablan and Yousfi (2011) examined 17 nations across Middle East, Asia and Africa. Their findings show efficiency of IBs with average of 92.72 percent where most efficient region are Pakistan and Malaysian with average value 96 percent. Erol, F, Aydoğan, and Tunç (2014) found that IBs in Turkey are more profitable than CBs. Ajili and Bouri (2018) assert that IBs in GCC countries valued the effectiveness of SSBs much more than the CBs governance mechanisms. Indeed, a reasonable consensus in the literature suggesting that IBs improve firms profitability, however, research on Shari' ah supervisions in relation to firms performance is still low, particularly Shari, ah governance on the IBs performance (Nathan, 2010; Mollah \& Zaman, 2015). This study is therefore conducted to examine the IBs performance as well as the effects of SSB and BOD attributes along with firm level control variables on IBs performance in South Asian countries.

\section{Corporate Governance Index (CGI)}

For measuring the effectiveness of Shari'ah boards (Ajili \& Bouri, 2018) incorporated four features, SSB existence, SSB size, SSB experience and SSB education, in an index and found marginal effect on performance. On other side to find-out the accumulative effect of CG related items on firm performance. Mollah, Hassan, Al Farooque, and Mobarek (2017) constructed ICG based upon 12 board room characteristics using only data of the regular BODs of 52 IBs and $104 \mathrm{CBs}$. The result of t-test shows that IBs compared to CBs gain desirable ICG scores indicating that CG structure of IBs is relatively better than CBs. Moreover, consistent with the study of Cihák and Hesse (2010) they found that ICG of IBs is positively affecting the Z-score of IBs, suggesting IBs have underneath insolvency risk. They also find-out the effect of ICG on small and large IBs and concluded that large IBs are better capitalized to handle the risk. However, our study constructs a CG composite index on 15 characteristics of boardroom of both Shari'ah and CG items and it is hypothesizes that:

$H_{1}$ : ICG index will be positively associated with IB's performance. 


\section{SSB Size (SBS)}

Shari'ah governance, on which Islamic banking rests, is the system that notifies and facilitates all commercial activities of IBs. Keeping in view the complexity of working of SSBs many authors found positive and significant association between SSB size and IBs performance (Alman, 2012; Grassa \& Matoussi, 2014; Mollah \& Zaman, 2015). However, there are contradictory findings in the literature that support small size SSBs, and found them more efficient in developing consensus, reduces agency cost, better in communications and have good control and decision making (I. Khan, Khan, \& Tahir, 2017; Mollah \& Zaman, 2015; Quttainah, Song, \& Wu, 2013). In a study by M. Khan and Khan (2017) found negative significant impact on IBs financial performance in case of Pakistan and Malaysia. However, Hamza (2016) argued that large SSBs involve members having different expertise and abilities related to the various schools of fiqah therefore; large SSBs prompt a superior understanding of products \& services leading towards the improved performance.

$\mathrm{H}_{2}$ : SSB size will be positively associated with IBs' performance.

\section{SSB Member's University Education (SBE)}

Ownership over applicable information and aptitude empower the members to comprehend the nature and ramifications of submitted products for fatawa. Shari'ah understanding along with financial and accounting knowledge helps SSBs to be free for taking decision. Kakabadse, Yang, and Sanders (2010) stated that important element that reflects the quality of board is their education. Therefore, education positively impact the banks' performance (Haniffa \& Cooke, 2002; Cheng, Chan, \& Leung, 2010). Further, they enhance banks' competitiveness (Gabrielsson \& Huse, 2005). Haridan, Hassan, and Karbhari (2018) found that the quality of religious assurance provided by Shari; ah boards enhance the firms credibility. The quality of Shari; ah assurance depend upon the SSBs members understanding of financial knowledge and experience among others. According to Musibah and Alfattani (2014), highly qualified members of SSB contribute towards higher profits. I. Khan et al. (2017) found that members of the SSB holding accounting/finance/economics degrees in addition to the knowledge of Shari'ah are positively associated with the banks' performance. Indicating that profitability of IBs is increased by SSB members having background of accounting and finance.

$H_{3}$ : SSB financial knowledge/education will be positively associated with IBs performance.

\section{Board Size (BS)}

According to Ghayad (2008), larger board size is preferred to avoid communication hurdles in Islamic banking industry and found positive association between large board size and firm performance. De Andres and Vallelado (2008) argued that board size is expected to be large in case of banks because of business complexity, asymmetric information and changing behavior of the market as it exercises better monitoring and advising. However, there 
are contradictory findings that supports smaller size boards have improved performance (Belkhir, 2009). Moreover, small size BODs will give positive results and enhance the performance (Malik \& Makhdoom, 2016). In case of IBs no consensus has been established between board size and firm performance. Grassa and Matoussi (2014); Quttainah et al. (2013) found insignificant relationship between board size and firm performance. However, Shahzad Bukhari, Awan, and Ahmed (2013) establish positive association between board size and performance. Mollah and Zaman (2015); Bukair and Abdul Rahman (2015) found negative relationship, whereas Grassa, Matoussi, and Trabelsi (2010); Juras and Hinson (2008) have found no association.

$H_{4}$ : Board size will be positively associated with IBs performance

\section{Board Independence (BI)}

BODs referred as the body that significantly upholds the interest of all the stakeholders involved. To gain and further strengthen of stakeholders' interest it is important to take executive as well as non-executive members on the board. However, it is argued that nonexecutive BODs should be able to perform their assigned tasks effectively when they are working as independent board members; otherwise they will not be able to yield and impart unbiased decisions (De Andres \& Vallelado, 2008). BIs have least conflicts of interest while performing their duties such as monitoring and advising. Hence, a positive relationship between IBs and bank value is expected (Bukair \& Abdul Rahman, 2015; Quttainah et al., 2013).

$H_{5}$ : Independent directors will be positively associated with IBs performance.

\section{Board Meetings (BM)}

The frequency of board meetings considered the most important act in CG practices in order to understand the working of the board. Higher number of meetings gives the opportunity to meet, understand and resolve the outstanding issues, share ideas and give experienced advice to the management (Vafeas, 1999). However, higher frequency of BMs signals both proactive as well as reactive meanings. According to Malik and Makhdoom (2016); Mayur and Saravanan (2017), frequent meetings are not good for organization as it signals negative effect on the firm and decrease its performance. We hypothesized the relationship between board activities and firm performance as fallow:

$H_{6}$ : Number of board meetings will be positively associated with IBs performance.

\section{Ownership Structure (IO)}

To analyzed the relationship between IO and IBs' performance specially to identify the different forms of IO like institutional, family, foreign and state Ben Slama Zouari and 
Boulila Taktak (2014) found that bank having institutional ownership have negative relationship with performance. On the other side positive relationship has been found between IO'S and IBs performance (Juras \& Hinson, 2008; Rashid \& Jabeen, 2016) while, (Belkhir, 2009) found no relationship.

$H_{7}$ : Institutional ownership will be positively associated with IBs performance.

\section{Data and Methodology}

\section{Data}

This study used manually collected dataset on corporate governance variables. Corporate governance variables information could be available from Bank scope and Data stream data banks. However, due to the missing values and accuracy issues the study prefers to use hand collected data, which was though a tedious task. As many IBs reports were not on standardized format, annual reports format has been changed even within the banks and within the country. The final sample of the study comprises 31 banks containing 11 Islamic banks and 20 Islamic windows from 4 countries over the period of 2010 to 2016 which generate an unbalanced panel of 217 firms-year observations. The banks of our sample come from Bangladesh, Maldives, Pakistan and Sri Lanka. Table 1 shows the list of countries, no. of banks and \%age of observations from each country.

Table 1

Sample distribution

\begin{tabular}{lccccc}
\hline Countries & Islamic banks & $\begin{array}{c}\text { Conventional banks having } \\
\text { Islamic branches }\end{array}$ & $\begin{array}{c}\text { IBs plus CBs having } \\
\text { Islamic branches }\end{array}$ & $\begin{array}{c}\text { No. of Obs. } \\
\text { Percentage share } \\
\text { by country }\end{array}$ \\
\hline Bangladesh & 4 & 3 & 7 & 46 & $22.58 \%$ \\
Maldives & 1 & 1 & 2 & $9.45 \%$ & $67.74 \%$ \\
Pakistan & 5 & 16 & 21 & 730 & $7.22 \%$ \\
Sri Lanka & 1 & 0 & 31 & 192 & $100 \%$ \\
Total & 11 & 20 & 1 & \\
\hline
\end{tabular}

\section{Variables}

This study employs both market as well as accounting-based measures to examine the impact of Shari'ah governance and CG on IBs performance. Consistent with the study of De Andres and Vallelado (2008); Abdel-Baki and Leone Sciabolazza (2014); Mollah and Zaman (2015) our study has taken Return on assets and Return on equity as accounting based measures. Where Tobin's Q is applied as market-based measure which is aligns with the study of De Andres and Vallelado (2008); Abdel-Baki and Leone Sciabolazza (2014); Mollah et al. (2017).

ICG index is constructed on 15 attributes of boardroom. These attributes are: (i) Board Size (BS); coded one if the BS is smaller than its median value, zero otherwise. (ii) Independent Directors (ID); coded one if the board's independence is larger than its median value, zero otherwise. (iii) Female Director; coded one for female directorship on the board, zero otherwise. (iv) Board Meetings (BM); coded one if the board meetings 
are larger than the median value of the board meetings held in a year, zero otherwise. (v) Board Attendance; coded one if the board attendance is larger than $75 \%$ of board meetings held in year, otherwise zero. (vi) Board Committees (BCs); coded one if the number of BCs are larger than the median value of BCs, zero otherwise. (vii) Audit committee size (ACS): coded one if the BS is smaller than its median value, zero otherwise. (viii) Audit committee independence (ACI): coded one if the ACI is larger than its median value, zero otherwise. (ix) Audit committee meetings (ACM): coded one if the audit committee meetings are larger than the median value of the ACMs held in a year, zero otherwise. (x) CEO chair; coded one if duality exists, zero otherwise. (xi) Shari'ah board size; coded one if the SSB size is less than the median value of the SSB size, zero otherwise. (xii) Female member of the Shari'ah board; coded one if female member exist in Shari'ah board, zero otherwise. (xiii) SSB supervisory/advisory; coded one for supervisory role, zero otherwise. (xiv) Shart'ah board Meetings; coded one if the SSB meetings are larger than the median value of the SSB meetings held in a year, zero otherwise. (xv) Shari'ah board Education; coded one if the SSB members have knowledge of accounting, finance, economics or commerce, zero otherwise.

Table 2 reports the description of all variables, excluding ICG index as discussed in the above paragraph.

\section{Model}

To analyze the impact of SSBs on firm performance we applied Random Effects Model (REM) since, the nature and extend of CG related variables does not change frequently (Mollah et al., 2017; Mollah \& Zaman, 2015; Pathan \& Faff, 2013). REM is considered to be a best technique to access the relationship. Research model includes dependent variables, independent variables and control variables as well. These variables are given as under:

$$
\text { Performance }_{i t}=\beta_{0}+\beta_{1} I C G_{i t}+\beta_{2} S B_{i t}+\beta_{3} C G_{i t}+\beta_{4} X_{i t}+\epsilon_{i t}
$$

Where; $i$ go from 1 to 31 banks and t gets the values of 2010 to 2016 are parameters of estimated coefficients for each of the independent variables. IC $G_{i t}$ is the corporate governance index of IBs, is the matrix of Shari'ah supervision variables such as Shari'ah board size and education, represents matrix of board structure variables like board size, board meetings and independent directors and $X_{i t}$ is the matrix of control variables. And $\epsilon_{i t}$ is the error term. While, bank performance is measured using accounting measures like $R O A_{i t}, R O E_{i t}$, and market measure Tobins' $Q_{i t}$.

\section{Results and Discussion}

Table 3 reports the descriptive statistics of the study. The performance variables used in analysis are ROA, ROE and Tobins'Q having mean values of -0.03, 1.98 and 1.33 respectively. The minimum values of performance variables are negative that reflects crisis 


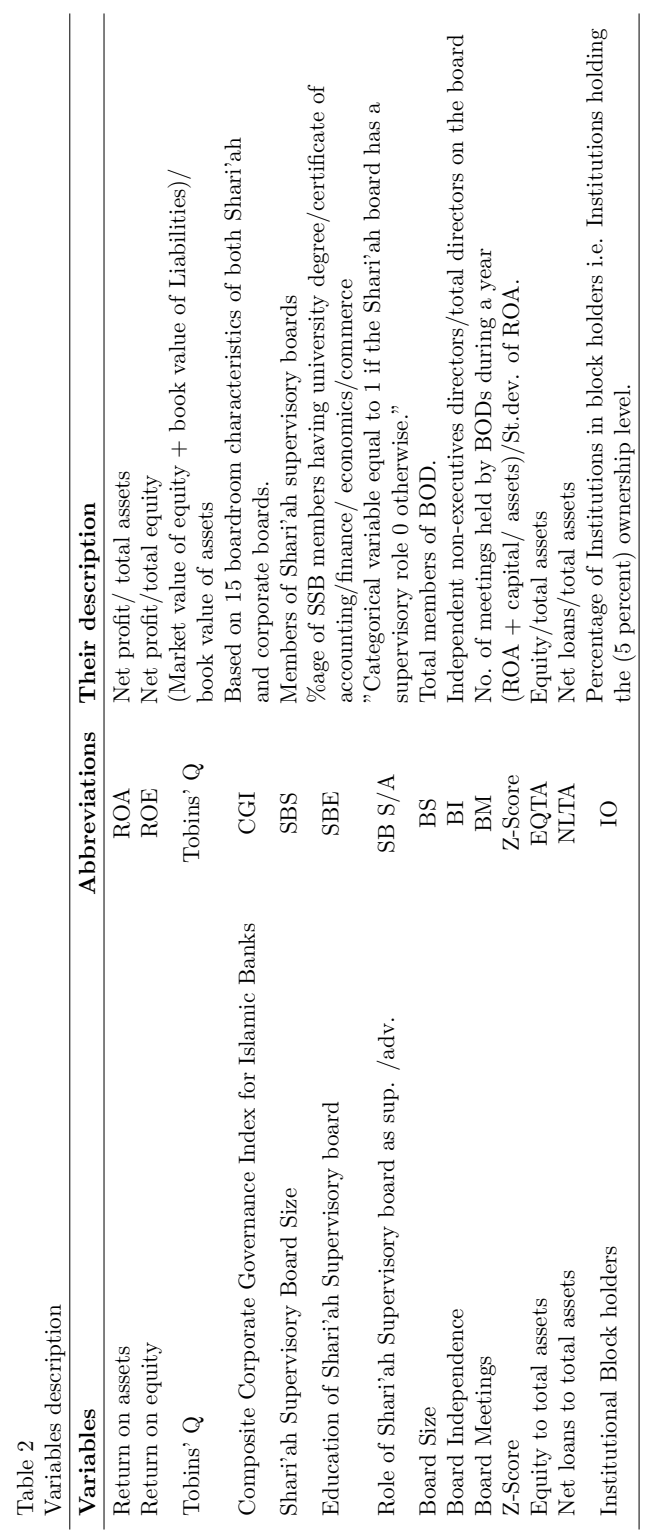


period effects since, the data set of the study starts from 2010 which is the initial period of recovery from global financial crisis. The comparison of Bangladesh and Pakistan of the financial performance variables shows that Bangladesh financial indicators are relatively better than Pakistan except ROA. Sample t-test between the two countries was applied to compare their mean differences of the variables utilized in the study. The other two countries i.e. Maldives and Sri Lanka were ignored because they both have just one IB each.

The level of ICG index is 48 percent ranging from 27 to 80 percent. The comparison of ICG between Bangladesh and Pakistan was found insignificant which shows that the corporate governance scores are almost similar in both the countries. The Shari'ah board attributes statistics shows an interesting story. Shari'ah board size was found 4 members on average with the minimum value of 1 and maximum 13. A deeper analysis of SSB size shows that few of the banks of Bangladesh actually inflate the overall average of South Asian countries for example, Islami bank of Bangladesh have on average 13 members in the board. While, the rest of the banks analyzed have on average 3 to 5 members. The comparison of Bangladesh and Pakistan Shari'ah board size indicate that the Bangladesh has more Shari'ah board members on average than Pakistan. Shari'ah board members university education of finance related is just 9 percent with the minimum value of 0 and maximum value of 66.66 percent in case of Meezan bank of Pakistan and Bank Islami of Bangladesh respectively. The comparison of Bangladesh and Pakistan Shari'ah board members university education of finance related demonstrate that SSB members of Pakistan have more knowledge of accounting and finance as compared to Bangladesh.

BOD size was found 10 members on average with the minimum value of 4 as in the case of ICB Islamic Bank Bangladesh and maximum value of 20 as in case of Islami bank and Shahjalal bank of Bangladesh. BOD independence was found 8.25 percent with the minimum value of 0 in case of ICB Islamic bank Bangladesh, Meezan Bank Pakistan and Burj bank Pakistan and maximum value of 53.84 percent in case of Bank Al Baraka Pakistan which employs that Pakistani IBs have more independent directors. While, the sample t-test between the two countries regarding board independence was found insignificance. Average board meetings were found around 10 meetings a year with a range of 3 to 48. The sample t-test was found positive and significant showing that Bangladeshi banks on average holds more meetings than Pakistani Islamic banks. One half of the ownership of IBs in South Asia is institutional ownership and Pakistani banks hold relatively defused ownership structure than Bangladesh.

Table 4 presents the empirical results of the study by applying panel random effects model. For empirical estimation we adopted an incremental methodology, started from the impact of ICG and Shari'ah governance on performance variables i.e. Tobin's Q, ROA and ROE shown in Model 1, Table 4. In each of the Model 2, Table 4 we incorporated the corporate governance attributes along with Shari; ah variables. Four firm level control variables namely EQTA, NLTA, log of total assets (LnTA) and Z-score were used for the empirical investigation.ICG index was found consistently insignificant in all of the 6 models results, this does not supports hypothesis H1. This finding is consistent with the work of (Ajili \& Bouri, 2018). SBS is found positively significant for all the three performance variables. The significance of the SBS was consistent with the work of Alman (2012); 
Mollah and Zaman (2015); Quttainah et al. (2013) which illustrates that larger Shari'ah board size is influential in enhancing the overall financial performance of the IBs.

Table 3

Descriptive statistics

\begin{tabular}{lcccccccc}
\hline Variables & N & Mean & St.dev. & Min. & Max. & $\begin{array}{c}\text { Bangladesh } \\
\text { sample mean }\end{array}$ & $\begin{array}{c}\text { Pakistan } \\
\text { sample mean }\end{array}$ & Sample t-test \\
\hline Return on Assets (ROA) & 191 & -0.03 & 1.45 & -9.97 & 3.01 & -0.2 & 0.08 & -1.26 \\
Return on Equity (ROE) & 191 & 1.98 & 7.37 & -23.63 & 30.71 & 3.29 & 1.7 & 1.24 \\
Tobins' Q & 77 & 1.33 & 1.25 & 0.16 & 10.02 & 1.99 & 0.93 & $3.25^{* *}$ \\
CGI & 191 & 0.48 & 0.12 & 0.27 & 0.8 & 0.47 & 0.46 & 0.37 \\
Shari' ah board size & 190 & 3.83 & 3.02 & 1 & 13 & 8.11 & 2.33 & $17.91^{* * *}$ \\
Shari' ah board education & 189 & 9.07 & 16.96 & 0 & 66.66 & 5.51 & 8.69 & -1.09 \\
Board size & 207 & 9.66 & 3.58 & 4 & 20 & 13.86 & 8.36 & $11.48^{* * *}$ \\
Board independence & 207 & 8.25 & 13.69 & 0 & 53.84 & 9.56 & 6.34 & 1.43 \\
Board meetings & 207 & 10.24 & 9.36 & 3 & 48 & 22.97 & 6.24 & $14.82^{* * *}$ \\
Audit committee size & 201 & 3.77 & 1.03 & 2 & 6 & 4.46 & 3.47 & $6.28^{* * *}$ \\
Institutional ownership & 204 & 22.69 & 32.66 & 0 & 100 & 25.24 & 15.73 & $1.96^{* *}$ \\
EQTA & 195 & 0.1 & 0.11 & 0 & 0.9 & 0.16 & 0.08 & $3.77^{* * *}$ \\
NLTA & 188 & 0.35 & 0.21 & -0.84 & 0.75 & -0.001 & 0.42 & $-14.78^{* * *}$ \\
LnTA & 202 & 12.95 & 2.7 & 4.62 & 22.05 & 13.57 & 13.04 & 1.12 \\
Z-score & 181 & 1.59 & 2 & -0.52 & 13.45 & 3.43 & 0.98 & $7.15^{* * *}$ \\
\hline Note: ${ }^{* * *} \mathrm{p}<0.01,{ }^{* *} \mathrm{p}<0.05,{ }^{*} \mathrm{p}<0.1$. & & & & & &
\end{tabular}

The larger Shari'ah board size having diverse experience and expertise could be more beneficial for value enhancing of the firm. Since, the complexity of the work of Shari'ah board is high as they not only take care of the Shari'ah adherence of newly developed products \&services but also involve in Shari'ah audit, disposal and distribution of income to IAHs and answered the issues and quarries raised by the stakeholders and general public at large. Keeping in view the rapid growth of IBs and its initial stage into the banking business, as majority of the IBs have age less than 10 years, the larger Shari'ah board size could be required to handle all these challenges especially the challenge of immature fatawas that could cause products withdrawals and Shari'ah non adherence that lead to customer mistress on IBs. This results supports the H2 of the study. SBE is found consistently insignificant in our analysis which may indicate the poor finance related knowledge of South Asian Shari; ah board. Though, this results contradictory many of the previous studies conducted on Islamic banking in which Shari; ah board was considered an important element, however keeping in consideration that just $9 \%$ of the Shari; ah board members have degree related to finance, accounting and economics in case of South Asian countries. This result rejects $\mathrm{H} 3$.

Banking business complexity requires relatively larger board size. After the global financial crisis not only the board size matters its independence is more pushed by the regulators. BS is also found significant for all the three performance variables consistent with the work of Grassa and Matoussi (2014); Quttainah et al. (2013); Shahzad Bukhari et al. (2013). Thus, H4 is accepted. BI was found negative and significant in case of ROE and Tobins' Q and insignificant in case of ROA which not supported H5. The board meeting variable was found negatively significant in case of $\mathrm{ROE}$ which reflects that more frequent meetings may have negative effect on financial performance as they signals reactive. Hence, $\mathrm{H} 6$ is also rejected. The audit committee size was also found insignificant except negatively significant in case of ROE. The ownership structure was measured through institutional 
ownership and variable was found significant. This reveals that IO exerts a positive effect on financial performance and supported H8.

In case of control variables EQTA was consistent negatively significant which may employs that all the finances in Islamic banks comes from IAHs and the capital structure of the IBs does not allowed debts components which restricts their leverage. The log of total assets was found consistently significant in all of the models which may employs that larger banks have higher performance.

Table 4

Regression Results

\begin{tabular}{|c|c|c|c|c|c|c|}
\hline \multirow[t]{2}{*}{ Variables } & \multicolumn{2}{|c|}{ ROA } & \multicolumn{2}{|c|}{ ROE } & \multicolumn{2}{|c|}{ Tobins' Q } \\
\hline & 1 & 2 & 1 & 2 & 1 & 2 \\
\hline \multirow[t]{2}{*}{ CGI } & -0.648 & -1.001 & -5.12 & -7.943 & -1.573 & -1.744 \\
\hline & -1.321 & -1.467 & -6.526 & -6.982 & -1.171 & -2.664 \\
\hline \multirow[t]{2}{*}{ Shari'ah board Size (SBS) } & $0.119^{* *}$ & $0.084^{*}$ & $0.683^{* *}$ & $0.853^{* * *}$ & 0.001 & $0.324^{* * *}$ \\
\hline & -0.052 & -0.057 & -0.307 & -0.281 & -0.094 & -0.112 \\
\hline \multirow[t]{2}{*}{ Shari'ah board Education (SBE) } & 0.013 & -0.003 & $0.141^{* * * *}$ & 0.071 & -0.007 & -0.002 \\
\hline & -0.009 & -0.009 & -0.047 & -0.045 & -0.011 & -0.014 \\
\hline \multirow[t]{2}{*}{ Board Size (BS) } & - & $0.093^{* *}$ & - & $0.563^{* * *}$ & - & $0.195^{* *}$ \\
\hline & & -0.042 & & -0.191 & & -0.078 \\
\hline \multirow{2}{*}{ Board Independence (BI) } & - & -0.008 & - & $-0.121^{* *}$ & - & $-0.024^{*}$ \\
\hline & & -0.011 & & -0.052 & & -0.015 \\
\hline \multirow[t]{2}{*}{ Board Meetings (BM) } & - & -0.056 & - & $-0.428^{* * *}$ & - & 0.061 \\
\hline & & -0.035 & & -0.162 & & -0.063 \\
\hline \multirow[t]{2}{*}{ Audit committee size (ACS) } & & -0.151 & & $-1.163^{* * *}$ & & 0.064 \\
\hline & & -0.096 & & -0.466 & & -0.156 \\
\hline \multirow[t]{2}{*}{ Institutional ownership (IO) } & - & $0.012^{* * *}$ & - & $0.104^{* * *}$ & - & -0.004 \\
\hline & & -0.005 & & -0.026 & & -0.006 \\
\hline \multirow[t]{2}{*}{ EQTA } & $-6.847 * * *$ & $-6.702^{* * *}$ & $-9.556^{* *}$ & $-10.400 * * *$ & $-2.538 * * *$ & -1.368 \\
\hline & -0.815 & -0.802 & -3.654 & -3.414 & -0.802 & -0.972 \\
\hline \multirow[t]{2}{*}{ NLTA } & 0.304 & 0.408 & 0.181 & 3.641 & -0.633 & -0.809 \\
\hline & -0.612 & -0.681 & -3.051 & -2.973 & -0.693 & -0.84 \\
\hline \multirow[t]{2}{*}{ LnTA } & $0.111^{*}$ & $0.104^{*}$ & $0.942^{* *}$ & $1.077^{* *}$ & $-0.242^{* * *}$ & $-0.199^{* *}$ \\
\hline & -0.056 & -0.053 & -0.339 & -0.027 & -0.077 & -0.084 \\
\hline \multirow[t]{2}{*}{ Z-score } & -0.06 & -0.062 & 0.379 & 0.286 & 0.04 & 0.049 \\
\hline & -0.07 & -0.066 & -0.394 & -0.328 & -0.095 & -0.094 \\
\hline \multirow[t]{2}{*}{ Constant } & -0.975 & -0.542 & $-11.303^{* *}$ & $-9.389^{*}$ & $6.197 * * *$ & $5.038^{*}$ \\
\hline & -0.951 & -0.997 & -5.367 & -4.873 & -1.652 & -2.616 \\
\hline Observations & 167 & 161 & 167 & 161 & 76 & 70 \\
\hline Overall $R^{2}$ & 0.47 & 0.55 & 0.32 & 0.64 & 0.08 & 0.39 \\
\hline Wald $C h i^{2}$ & $106.76^{* * *}$ & $184.22^{* * *}$ & $44.19^{* * *}$ & $140.64^{* * *}$ & $19.81^{* * *}$ & $37.97^{* * *}$ \\
\hline
\end{tabular}

\section{Conclusion and Policy Recommendations}

This study investigates the relationship between "multi-layer" corporate governance of IBs and their performance in case of South Asia for the period of 2010-2016. The sample of the study comprises of 31 IBs consisting 11 full-fledged Islamic banks and 20 conventional banks having Islamic banking branches from 4 countries namely Bangladesh, Maldives, Pakistan and Sri Lanka. Handpicked data was used to analyze the empirical models and unbalanced panel of 217 firm-year observations were used to analyze the empirical model. The study contributes mainly in three ways into the literature of the IBs. Firstly, we considered 
a region that consists of $40 \%$ of the Muslims population and are religiously motivated, enormous Islamic banking potential exists in the region, majority of the previous literature on IBs mainly focused on the GCC countries or South East Asia. First, this study focused a relatively ignored zone by investigating the Shari'ah governance and IBs performance. Secondly, we constructed ICG index for IBs considering 15 boardroom items. Thirdly, this study is the first that has analyzed the effect of Shari'ah governance on IBs performance in case of South Asia.

Two types of estimation techniques were applied to the data sets first, descriptive statistics and sample t-test and second, panel regression. The ICG index was ranked to estimate the good corporate governance characteristics of four countries under consideration. It was found the Islamic banks of Bangladesh gets higher scores due to their larger SB size, corporate board, board independence and board meetings compare to others countries in South Asian region. The sample t-test between Bangladesh and Pakistan was also applied to test the mean difference of $\mathrm{CG}$ characteristics of both countries having larger market shares in Islamic banking and it was found that Bangladeshi Islamic banks have higher mean except ROA.

By applying panel REM the results of the study reveals that large Shari'ah and corporate board are value enhancing. This may asserts that keeping in view the complexity of banking businesses demands larger boards in improving the financial performance.

Few important policy recommendations are derived from our estimated models (i) ICG was consistently found insignificant on firm performance, which may indicates that the CG practices have little influence on firm value. The CG codes and standards of the IBs are internationally developed by two main organizations i.e. IFSB and AAOIFI, however no such enforcement is observed in case of IBs in South Asia. Being relatively new institutions, the local regulators enforced the same conventional banking standards and principles. It is therefore, suggested to local and international regulators of the IBs to develop an international committee that coordinate, design and formulate standardized CG codes and implement them like Basel committee on the banking supervision (ii) secondly the results of the study reveals that the large boards are value enhancing which may employs that large and diverse boards brings knowledge, experience, expertise and widen strategic views. It is therefore suggested to the regulators that the board size may be increase in the IBs industry. 


\section{References}

Abdel-Baki, M., \& Leone Sciabolazza, V. (2014). A consensus-based corporate governance paradigm for Islamic banks. Qualitative Research in Financial Markets, 6(1), 93108.

Aebi, V., Sabato, G., \& Schmid, M. (2012). Risk management, corporate governance, and bank performance in the financial crisis. Journal of Banking $\&$ Finance, 36(12), 3213-3226.

Ajili, H., \& Bouri, A. (2018). Assessing the moderating effect of Shariah board on the relationship between financial performance and accounting disclosure. Managerial Finance, 44(5), 570-589.

Al-Malkawi, H.-A. N., \& Pillai, R. (2018). Analyzing financial performance by integrating conventional governance mechanisms into the GCC islamic banking framework. Managerial Finance, 44(5), 604-623.

Alman, M. (2012). Shari'ah supervisory board composition effects on Islamic banks' risktaking behavior. Journal of Banking Regulation, 14(1), 134-163.

Ashraf, S., Robson, J., \& Sekhon, Y. (2015). Consumer trust and confidence in the compliance of islamic banks. Journal of Financial Services Marketing, 20(2), 133144.

Beck, T., Demirgüç-Kunt, A., \& Merrouche, O. (2010). Islamic vs. conventional banking: Business model, efficiency and stability. Journal of Banking 8 Finance, 37(2), 433447.

Belkhir, M. (2009). Board of directors' size and performance in the banking industry. International Journal of Managerial Finance, 5(2), 201-221.

Ben Slama Zouari, S., \& Boulila Taktak, N. (2014). Ownership structure and financial performance in Islamic banks: Does bank ownership matter? International Journal of Islamic and Middle Eastern Finance and Management, 7(2), 146-160.

Bhatti, M., \& Bhatti, M. I. (2010). Toward understanding Islamic corporate governance issues in Islamic finance. Asian Politics $\&$ Policy, 2(1), 25-38.

Bitar, M., Madiès, P., \& Taramasco, O. (2017). What makes Islamic banks different? A multivariate approach. Economic Systems, 41(2), 215-235.

Bukair, A. A., \& Abdul Rahman, A. (2015). Bank performance and board of directors attributes by Islamic banks. International Journal of Islamic and Middle Eastern Finance and Management, 8(3), 291-309.

Chapra, M. U. (2009). The global financial crisis can islamic finance help? Insights, 1(4), $27-38$.

Chapra, M. U., \& Ahmed, H. (2002). Corporate governance in islamic financial institutions. Islamic Development Bank Jeddah.

Chazi, A., Khallaf, A., \& Zantout, Z. (2018). Corporate governance and bank performance: Islamic versus non-islamic banks in GCC countries. The Journal of Developing Areas, 52(2), 109-126.

Cheng, L. T., Chan, R. Y., \& Leung, T. (2010). Management demography and corporate performance: Evidence from China. International Business Review, 19(3), 261-275. 
Čihák, M., \& Hesse, H. (2010). Islamic banks and financial stability: An empirical analysis. Journal of Financial Services Research, 38(2-3), 95-113.

De Andres, P., \& Vallelado, E. (2008). Corporate governance in banking: The role of the board of directors. Journal of Banking 85 Finance, 32(12), 2570-2580.

Erol, C., F, H., Baklaci, Aydoğan, B., \& Tunç, G. (2014). Performance comparison of Islamic (participation) banks and commercial banks in Turkish banking sector. EuroMed Journal of Business, 9(2), 114-128.

Gabrielsson, J., \& Huse, M. (2005). Outside directors in SME boards: A call for theoretical reflections. Corporate Board: Role, Duties and Composition, 1(1), 28-37.

Ghayad, R. (2008). Corporate governance and the global performance of Islamic banks. Humanomics, $24(3), 207-216$.

Grassa, R., \& Matoussi, H. (2014). Corporate governance of Islamic banks: A comparative study between GCC and Southeast Asia countries. International Journal of Islamic and Middle Eastern Finance and Management, 7(3), 346-362.

Grassa, R., Matoussi, H., \& Trabelsi, S. (2010). The impact of Shariah supervisory board characteristics on Islamic bank performance. In Corporate Governance and the Global Financial Crisis Conference, Wharton, University of Pennsylvania, Philadelphia.

Green, S. (2010). Global perspective on Islamic finance. LSE-Harvard Public Lecture on Islamic Finance.

Hamza, H. (2016). Does investment deposit return in Islamic banks reflect PLS principle? Borsa Istanbul Review, 16(1), 32-42.

Haniffa, R. M., \& Cooke, T. E. (2002). Culture, corporate governance and disclosure in Malaysian corporations. Abacus, 38(3), 317-349.

Haridan, N. M., Hassan, A. F., \& Karbhari, Y. (2018). Governance, religious assurance and Islamic banks: Do Shariah boards effectively serve? Journal of Management and Governance, 22(4), 1015-1043.

Hasan, M., \& Dridi, J. (2011). The effects of the global crisis on islamic and conventional banks: A comparative study. Journal of International Commerce, Economics and Policy, 2(02), 163-200.

Iqbal, M. (2001). Islamic and conventional banking in the nineties: A comparative study. Islamic Economic Studies, 8(2), 1-28.

Islam, J. U., \& Rahman, Z. (2017). Awareness and willingness towards Islamic banking among Muslims: An Indian perspective. International Journal of Islamic and Middle Eastern Finance and Management, 10(1), 92-101.

Juras, P. E., \& Hinson, Y. L. (2008). Examining the effect of board characteristics on agency costs and selected performance measures in banks. Academy of Banking Studies Journal, 7(1/2), 87-107.

Kablan, S., \& Yousfi, O. (2011). Efficiency of islamic and conventional banks in countries with Islamic banking. paper no. 32951, mpra, paris.

Kakabadse, N. K., Yang, H., \& Sanders, R. (2010). The effectiveness of non-executive directors in Chinese state-owned enterprises. Management Decision, 48(7), 10631079 .

Kassim, S. H., \& Abdulle, M. Y. (2012). Impact of global financial crisis on the performance of Islamic and conventional banks: Empirical evidence from Malaysia. Journal of 
Islamic Economics, Banking and Finance, 113(470), 1-12.

Khan, I., Khan, M., \& Tahir, M. (2017). Performance comparison of Islamic and conventional banks: Empirical evidence from Pakistan. International Journal of Islamic and Middle Eastern Finance and Management, 10(3), 419-433.

Khan, M., \& Khan, I. (2017). Corporate governance in Islamic Banking: The role of board of directors. COMSATS Journal of Islamic Finance, 2(1), 47-55.

Malik, M. S., \& Makhdoom, D. D. (2016). Does corporate governance beget firm performance in fortune global 500 companies? Corporate Governance, 16(4), 747-764.

Mansour, W., \& Bhatti, M. I. (2018). The new paradigm of islamic corporate governance. Managerial Finance, 44(5), 513-523.

Mayur, M., \& Saravanan, P. (2017). Performance implications of board size, composition and activity: Empirical evidence from the Indian banking sector. Corporate Governance: The international Journal of Business in Society, 17(3), 466-489.

Mollah, S., Hassan, M. K., Al Farooque, O., \& Mobarek, A. (2017). The governance, risktaking, and performance of Islamic banks. Journal of Financial Services Research, $51(2), 195-219$.

Mollah, S., \& Zaman, M. (2015). Shari'ah supervision, corporate governance and performance: Conventional vs. Islamic banks. Journal of Banking \& Finance, 58, 418-435.

Musibah, A. S., \& Alfattani, W. S. B. W. Y. (2014). The mediating effect of financial performance on the relationship between Shariah supervisory board effectiveness, intellectual capital and corporate social responsibility, of islamic banks in Gulf Cooperation Council countries. Asian Social Science, 10(17), 139-164.

Nathan, S. (2010). The performance of Shari'ah supervisory boards within Islamic financial institutions in the gulf cooperation council countries. Corporate Ownership 83 Control, 8(1), 247-266.

Pathan, S., \& Faff, R. (2013). Does board structure in banks really affect their performance? Journal of Banking \& Finance, 37(5), 1573-1589.

Perry, F. V., \& Rehman, S. S. (2011). Globalization of Islamic finance: Myth or reality. International Journal of Humanities and Social Science, 1(19), 107-119.

Quttainah, M. A., Song, L., \& Wu, Q. (2013). Do Islamic banks employ less earnings management? Journal of International Financial Management $\&$ Accounting, 24(3), 203-233.

Rashid, A., \& Jabeen, S. (2016). Analyzing performance determinants: Conventional versus Islamic banks in Pakistan. Borsa Istanbul Review, 16(2), 92-107.

Saleh Salman, A., Zeitun, R., et al. (2006). Islamic banking performance in the Middle East: A Case Study of Jordan (Tech. Rep.).

Shahzad Bukhari, K., Awan, H. M., \& Ahmed, F. (2013). An evaluation of corporate governance practices of Islamic banks versus Islamic bank windows of conventional banks: A case of Pakistan. Management Research Review, 36(4), 400-416.

Vafeas, N. (1999). Board meeting frequency and firm performance. Journal of Financial Economics, 53(1), 113-142. 